\title{
ECONOMIC ASPECTS OF MIGRATION FROM CENTRAL ASIA IN RUSSIA
}

\author{
J. Virkkunen \\ University of Eastern Finland \\ Yliopistokatu str., 2, PL 111, Joensuu, Finland, 80101
}

\begin{abstract}
The feeling of 'home' and 'ontological security' are central in social and psychological integration of both migrants and local residents. In Russia, for most Central Asian migrants the feeling of 'home' is often in clear contradiction with daily practices in Russia. The tightening economic situation, collapse of the rouble and the ambivalent migration legislation, of course, affect the integration of migrants and a feeling of security in the new countries of residence.
\end{abstract}

Key words: ontological security, Central Asia countries, migration to Russia, refugee crisis, Integration of migrants into the host society

\section{Introduction}

Migration is one of the contested issues of the contemporary time. The language used in discussing and describing populations moving across international border has become stricter and, among some circles, physical attacks against foreign-looking nationals are represented heroic acts, attempts to protect homeland from 'illegals', 'potential terrorists' and 'welfare shoppers'. In many counties of Europe, the 2015 'refugee crisis' and the above-mentioned expressions have had a direct impact on security. With its estimated 10 million foreign nationals, Russia is the second largest immigration country in the world. Despite a great demand for foreign labour force in certain regions and sectors of economy, the overall attitude to 'immigrants' is rather negative and securitized also in Russia. After exploring this migration-security nexus in overall terms, the paper will discuss the meaning of 'home' and so-called 'ontological security' among Central Asian migrants in Russia.

The feeling of 'home' and 'ontological security' are central in social and psychological integration of migrants and locals respectively. These micro layers of security reflect the changing everyday contexts, personal and local (in)securities and different personal and community level strategies to host, integrate and cope with these insecurities. In the context of the growing economic crisis and the weakening Rouble, contradictory migration policies, and local-level migration related disputes have, clearly, created a setting where migrants not only reconsider their lives 'in-between' Russia and Central Asia but also in relation to their social and territorial loyalties, religion and sets of values. In concrete, these are central for migrants' lives, families and integration to (or with) the Russian society and, ultimately, to the way they see their future lives as part of Russian or Central Asian societies. 


\section{Home for Migrants}

The concept of home is multi-layered. It captures well the complex character of individuals' relation to identity, place, self / family, and society. Home refers to three main categories: Home as the symbol of identity, Home as private (closed) space and Home as public (open/closed) space (Brednikova O., Tkach O., 2010; Buffel T., Phillipson C., 2016; Ralph D., Staheli L.A., 2011). The first - home as the symbol of identity - is closely related to the comfort that home brings along with all the memories, feeling of longing, routines and good life. At home the person knows who he/she is, and is free to be and express oneself, without feeling the pressure of the outside world. It is more than just a flat or an apartment. People leave home to the 'external' world (city, work, etc.) and come back. In other words, the home as place of comfort exists only in dialogue with that outside world.

At the second level - home as private (closed) space - home is a concrete place, a house or an apartment that is open for outsiders only by invitation. This, very closely related to the symbol of identity where especially family and care give that particular place its meanings characterized by love (or, in some cases fear). It consists of everyday life, practices, routines and traditions that give our lives and that particular space a specific significance. Lastly, home as public (open/closed) space brings the feeling of home a wider context of city, homeland, ethnic and cultural belonging. Despite its more abstract character, it becomes very concrete through language, ethnic or national belonging. Here, the public sphere, e.g. state, politics and external actors, provide a certain setting for familiarity, communality, and comfort, a place where the person can feel welcome and understood. However, as witnessed in the case of bad relations within family, domestic violence, or racism, these ideal 'homes' are neither stable nor always positive. They are changing in dialogue and in everyday contexts within which individuals operate.

For migrants, the above-described three-fold conceptualisation of 'home' is rather complicated. Migrants often live in a transnational space 'in-between' where home is neither 'here' nor 'there'. Their loved ones are 'at home' thousands of kilometres away and everyday relations and care practices (related to children and aging parents) are carried out through mobile phones or other new technologies such as Skype (Baldassar L., 2016). At the same time, migrants' housing can consist of shady huts, over-crowded shared flats, often referred to as 'rubber flats', or bunking at some friends or distant relatives. The social networks of family members, friends and other peer compatriots, and related spaces of socialisation such as 'migrant cafes' and restaurants, as well as familiar tastes and smells from 'home', can make a significant context within which migrants construct their lives. Whereas the outside world can seem hostile due to racism and anti-migrant sentiments, and everyday struggles with work, housing and the formal status, 'home' for migrants can be a source for feelings of insecurity and inequality rather than comfort.

In Russia, for most Central Asian migrants 'home' is a contradictory process where memories and cultural practices 'from home' in Central Asia are often in clear contradiction with real-life, or expected, daily practices in Russia. These are related to migrants' everyday life in an entirely different (and rapidly changing) context, often without family. 


\section{Changing everyday context}

Most Central Asian labour migrants in Russia live in precarious conditions. In 2015, Russia granted work permit and work licences (patents) for 1,887,034 foreign citizens, most of which came from the CIS countries of Uzbekistan $(899,864)$, Tajikistan $(445,652)$, Ukraine $(209,840)$ and Moldova $(99,835)$. The largest groups of non-CIS migrants were Chinese $(51,701)$, North Koreans $(30,757)$, Turkish $(20,414)$, and Vietnamese $(12,522)$ (Ryazantsev, Manshin, 2016). However, these figures make only a small share of the total estimated 10 million foreign citizens residing and working in the country.

Within this overall context, we can observe three interrelated developments in Russian society that have a significant impact on 'migrant homes' in contemporary Russia: (1) The changing economic and political realities of the Russian society, (2) Three-tier migration policies and tightening migration control, and (3) Psychological and cultural exhaustion for migration.

\section{Economic and political realities}

Connected to the global economic decline, the geopolitically inspired sanction policy and the structural challenges in the Russian economy, especially the changing value of both rouble and oil, many companies are in trouble. As the value of the Rouble mirrored almost perfectly the value of oil, the most important export item of the Russian economy, the sharp fall in the price of oil from about USD100 per barrel in mid-2014 to USD40 in early 2015 was directly reflected in the value of the rouble. During the 'economic crisis' the ruble price of the dollar has approximately doubled ${ }^{1}$. Consequently, the state budget is heavily in deficit and subsidised from state reserves.

Despite a rapid decrease in ability to travel and buy foreign goods, the domestic purchasing power had declined relatively little, by about $10 \%$ (ibid.). Officially, the unemployment is still not more than 5.6 percent (much higher in real life) but significantly lower investment $(-7.6 \%)$, tightening consumption $(-9.6 \%)$ and retail sales $(-9.7 \%)$ put a record number of companies to adapt their performance to the new economic realities $^{2}$. The main sectors of migrant labour market, services and construction, were among the sectors facing the decrease heaviest, which increased the already tight competition and restructuring of the 'migrant labour market' as well.

Related to the strong prevalence of shadow economy in Russia, almost every sector of the Russian economy makes use of the migrant labour. In many cases migrants conduct the work, unofficially and for smaller salaries, that are officially carried out by locals (Ryazantsev, 2016). This practice, consequently, gives migrants access to paid work but a lower salaries than locals. It also supports diverse structures of exploitation, violation of workers' rights and inequality that all contribute to a certain feelings of inferiority among migrants. Nevertheless, the pressure in Russian labour market increased and

1 BOFIT. Viikkokatsaus 31. Suomen pankki. 4.8.2016. [Electronic Resource]. Access Mode: http:// www.suomenpankki.fi/bofit/seuranta/viikkokatsaus; Strazds A., Grennes T. The Russian Economic Crisis: How Severe and How Long? Economonitor. 17.5.2016. [Electronic Resource]. Access Mode: https://shar.es/187ycx

${ }^{2}$ Focus Economics. Russia Economic Outlook. 21.10.2016. [Electronic Resource]. Access Mode: http://www.focus-economics.com/countries/russia 
encouraged nationalist sentiments and additional anti-migrant discourses, as well as discussions of the character and actual need of foreign labour.

Like in other European states, Central Asian migrants have become popular scapegoats for different societal and everyday problems such as unemployment. At the local level in Moscow, the locals considered the number of immigrants way higher than it actually was. For them, immigrants represented some concrete everyday troubles like overpopulation and traffic jams related to the 'crowded city' rather than anti-migrants sentiments in general (Kosmarskaya N., Savin I., 2016). However, there are wide regional differences in the attitude to the foreign labour, creating rather different contexts where the abovedescribed inequalities, racist discourses and attacks and religious-political assaults are being lived and interpreted.

\section{Legal status, corruption and deportations}

The second aspect of having an impact of migrants' everyday setting is closely related to the political realities and, significantly, the tightening immigration control of the Russian state. The Russian migration policy has three categories of immigrants based on citizenship, two first ones concern migrants from Central Asia. Citizens of the Eurasian Economic Union (EEU) - Armenia, Belarus, Kazakhstan and Kyrgyzstan - enjoy free movement and can relocate to and work in Russia with no limitations. They need neither work permits nor work licences (patents, in Russian) and, thus, acquire equal labour rights at the Russian labour market with locals by registration. This not only increases the sense of security among migrants but, significantly, reduces the possible moments of corruption and undesirable encounters with police and authorities dealing with migration. The legal status of EEU citizens can enjoy equal salaries and working conditions with locals, and where they can relocate to Russia as a family, rather than alone or with friends. After Kyrgyz membership, for example, the possibility has, indeed, lead to an obvious increase in female and family migration.

More vulnerable than the EEU citizens are the citizens of the Commonwealth of Independent States (CIS). The decision to extend the work licence (patent) policy for all CIS citizens in January 2015, made the process of obtaining a legal labour migrant status significantly easier. The citizens of Azerbaijan, Moldova, Tajikistan, Turkmenistan, Uzbekistan and Ukraine do not need to apply for a special work permit but a licence with which they can live and work legally. Despite the positive intentions of this scheme, easy legalisation process, improved labour rights and social conditions, as well as better longterm perspectives for integration, the practical implementation licence policy became a failure. Not only do the migrants have to apply for foreign passport, insurance and medical certificate prior to arrival, they also need to pass examinations in Russian history, language and law within a month of relocating themselves to the territory of the Russian Federation.

For some migrants the new system certainly is a big improvement, a way to get away from the shadow economy. Most Central Asian migrants, however, earn very little and concentrate in saving money for remittances. For them, the new system is expensive. Apart from the estimated cost of 30-40,000 roubles (580 euros) 'starting fee' for the required documents and examinations, the monthly charge of a licence depends on the region. Despite the Russian average salary of about 36,100 roubles ( 520 euros), the income 
of many migrants does not exceed 25,000 roubles (360 euros). Consequently, the introduction of simplified procedures for CIS citizens in 2015 succeeded only partially, leaving majority of migrants to the precarious state of illegal work.

\section{Deportations and re-entry bans}

In order to reduce the so-called 'illegal migration' (or actually illegal work) in the Russian Federation, the Federal Migration Service (FMS) and the Police tightened their approach to migration in 2013. They increased the number of identification, document checks and arrests in construction sites, factories, markets, restaurants and other possible locations with migrants, which in many cases lead to rapid deportations and administrative re-entry bans. According to Director Konstantin Romodanovskiy from the Federal Migration Service, the aim of these was to reduce criminality and make 'illegal migration' legal (Gritsjuk M., 2015). He estimates that in the end of 2014 there were approximately 1.7 million foreign citizens who had exceeded the visa free limit by half a year, and about a million who have exceeded that for over a year. This, of course, means that there are over a million foreign citizens in Russia who live under a constant pressure of getting caught and being deported.

In 2014, illegal work, illegal stay, criminal offences and other causes lead to the deportation of 129,034 foreign citizens. In addition to that, Russian authorities issued a so-called re-entry ban for up to 675,950 persons as an administrative procedure (Kazmierkiewicz P., 2016) ${ }^{1}$. These were based on different administrative violations such as jaywalk and parking fines. According to Kluczewska (Kluczewska K., 2014), "the mechanism of re-entry bans was created because for the Russian authorities it would be technically impossible and not cost-effective to identify and deport all foreign nationals who committed irregularities on the territory of the Russian Federation". However, due to the administrative character and decentralized management of the ban, many of the migrants were never informed by any of the eleven authorities involved. This has naturally led to inconvenient situations at the Russian airports and border crossing points upon arrival. To avoid such situations, the Migration Service has established an internet based system through which migrants can before buying the ticket check if he/she is eligible to enter the country.

The impact of deportations and up to 10-year re-entry bans can mainly be felt in home and neighbouring countries in Central Asia. There are an increased number of people who are not only able to access Russia to provide income for their families in terms of remittances. Piotr Kazmierkiewicz (Kazmierkiewicz P., 2016) with his IOM colleagues remind us that the re-entry ban, usually $3-5$ years, slash the migrant households disposable income that may, further, have an impact on the entire migration dynamics in Central Asia. Migrants who are not able to return to Russia are looking for alternative migration destinations elsewhere. Simultaneously, they are subjected to various vulnerabilities such

${ }^{1}$ Federal Migration Service. The data was obtained on the official request in 2015; IOM. Tajik Migrants with Re-entry Bans to the Russian Federation. Dushanbe: IOM, 2014. [Electronic Resource]. Access Mode: https://publications.iom.int/books/tajik-migrants-re-entry-bans-russian-federation; ITAR-TASS. 600,000 migrants banned from entering Russia. 25.2.2015. [Electronic Resource]. Access Mode: http://tass.ru/en/russia/720901 
as exploitation by unverified mediators and manipulations by criminal and extremist networks. Majority of the migrants interviewed by the IOM (ibid.) had no alternative strategy for survival.

\section{Everyday and the ontological security of migrants}

The concept ontological security captures well the above-described everyday issues among migrants. Theoretically, the concept of ontological security is closely interwoven with the idea of trust and safety that give people (not only migrants) hope and courage against various everyday threats, pressures and fears, in relation with the surrounding communities (Debuis A., Thorns D., 1998; Noble G., 2005). The concept originates at Anthony Giddens's (Giddens A., 1996) well-known theorisation of ontological security reflecting individuals' need to answer existential questions about existence, stability of life, self, and interaction. In contrast to military or physical security, this is a space in which the routines of everyday life and existence can be performed, relatively free from external surveillance and, hence, offering (or, in some cases, preventing) the person a sense of autonomy.

In a particular context of immigrants, ontological security becomes significant through home-building that, according to Greg Noble (Noble G., 2005), must "constantly negotiate the affective and cognitive dissonance" and the acts of social incivility, harassment and abuse. Migrants attempt to find and secure their places in a world in social and economic contexts that are often characterized by racism, everyday worries triggering feelings of insecurity and inability to look forward, anticipate becoming possibilities, and give meanings to ones lives. This more abstract notion of 'homing' combines the threefold conceptualisation of 'home' described in the beginning of the paper (home as symbol of identity, private (closed) space, and public (open/closed) space) with a deeper meanings of everyday life. In other words, precarious migrant lives in overcrowded 'rubber flats' without privacy, unsecure employment and unfavourable exchange rates, combined with feeling of inequality, insecure social, economic and legal citizenship in the countries of residence are central to the ways Central Asian migrants conceptualize their lives and feeling of security in Russia.

A particularly high-risk group of migrants are the extremely poor, less educated and less experienced who not only are most vulnerable in terms of all forms of exploitation but who also possess fewer resources to be integrated with the new Russian context. Those groups are, thus, the primary target groups for pre-departure language training and awareness building as well as work license related examinations on Russian language, history and society. On the other hand, ability to keep contact with friends and the family 'at home' by phone or social media, be part of local social networks and, even, visit familiar 'ethnic spaces' such as Central Asian cafes and restaurants, is vital for ordering migrants' conception of everyday life in Russia.

After over a decade of extensive migration and remigration from Central Asia to precarious labour markets in Russia, and concrete social and family related troubles caused by the migration, many former migrants have started to question the actual benefits of the migration (Fryer P., Virkkunen J., Usmonov F., 2016; Virkkunen J., 2013). Despite a sharp decrease of remittances, migration is often the 'only' option for income for families 
in rural Central Asia. For the citizens of Kyrgyzstan, the country's membership of the Eurasian Economic Union has made the movement easier but they can still be subjected for corruption by authorities or arbitrary arrested by the police. As foreign citizens, they can also be deported due some criminal offences but, significantly, not issued administrative re-entry bans like the citizens of Uzbekistan or Tajikistan. Combined with the fact that Kyrgyz citizens do not have such a pressure for immediate registration or length of legal stay, this makes a big difference for the ontological security among Kyrgyz.

The Kyrgyz are also arriving in Russia increasingly as families. Even though there are no particular 'Kyrgyz towns' in Russia (vs. China towns elsewhere in the world), Kyrgyz are known of their 'ethnic spaces' with specific Kyrgyz infrastructure including cafes, restaurants, sports and night clubs, and medical centres (Varshaver E., Rocheva A., 2014; Varshaver E., Rocheva A., Kochkin E., Kuldina E., 2014) ${ }^{1}$. That so-called 'parallel city' not only indicates a certain indifference for integration but also a very rich ethnic dynamics where Kyrgyz can survive and enjoy services within the community, in Kyrgyz. The familiar smells and tastes in cafés (Virkkunen J., 2013), combined with other activities, may help in everyday practical and emotional issues, and feeling of security, far away from Kyrgyzstan. However, a rather strong social control within the Kyrgyz community may also lead to a very controlled living context and in-group violence, especially, against women ${ }^{2}$. From the ontological security perspective, the tight in-group dynamics lead by some conservative male leaders and so-called 'Patriots', does not only mean that a clear control of some female migrants. It also means that Russia may function as a liberating and empowering context for migrants from conservative families.

\section{Conclusion}

Many Central Asian migrants in Russia live in precarious conditions with shady overcrowded flats, uncertain employment conditions or utterly unclear work and residence status. Combined with the tightening economic situation, collapse of the rouble and the ambivalent legislation setting the legal context for stay, the migrants' integration and feeling of safety and security in the new countries of residence are certainly influenced. These create concrete moments of difficulty but, significantly, also affect the migrants way of conceptualising their relation to 'home' but also to everyday but also the way they are able to trust and create a feeling of safety that give them (and not only migrants) hope and courage against various everyday threats, pressures and fears, in relation with the surrounding communities.

The membership of the Eurasian Economic Union ensures the citizens of Armenia, Belarus, Kazakhstan and Kyrgyzstan a special status that may guarantee more equal

${ }^{1}$ Luhn A. Why are migrants fleeing Moscow? Guardian. 08.06.2015. [Electronic Resource]. Access Mode: https://www.theguardian.com/cities/2015/jun/08/why-migrants-fleeing-moscow-permitseconomy

2 Botoeva G. Kyrgyz migrant workers: does national pride mean violence against women? OpenDemocracy, 21.9.2012. [Electronic Resource]. Access Mode: https://www.opendemocracy.net/ od-russia/gulzat-botoeva/kyrgyz-migrant-workers-does-national-pride-mean-violence-againstwomen; Tursunbekova A. Kyrgyzstan: Videos Abound of 'Patriotic' Attacks on Migrant Women in Russia. Global Voices, 16.6.2012. [Electronic Resource]. Access Mode: https://globalvoices. org/2012/06/16/kyrgyzstan-patriotic-attacks-against-migrant-women-fuel-outrage/ 
salaries and working conditions with locals. Other citizens of the CIS have a possibility to receive a work licence with some practical and financial effort, which means that not nearly as many migrants have actually legalized themselves as planned. They are as much subjected to possible deportations and administrative re-entry bans as earlier, leaving them in a possible state of limbo 'at home'. As agreed by a number of experts, including the IOM, these may subject migrants to serious insecurities and vulnerabilities such as exploitation by unverified mediators and manipulations by criminal and extremist networks. Therefore, it would be important for the states and international organisations to ensure a long-term solution both for migrant' rights in Russia and some future perspectives in Central Asia.

\section{REFERENCES}

Baldassar L. (2016). Mobilities and Communication Technologies: Transforming Care in Family Life / In: Kilkey M., Palenga-M llenbeck E. (eds.) Family Life in an Age of Migration and Mobility: Global Perspectives through the Life Course. London: Palgrave. Pp. 19-42.

BOFIT. Viikkokatsaus 31. Suomen pankki. 4.8.2016. [Electronic Resource]. Access Mode: http:// www.suomenpankki.fi/bofit/seuranta/viikkokatsaus

Botoeva G. Kyrgyz migrant workers: does national pride mean violence against women? OpenDemocracy, 21.9.2012. [Electronic Resource]. Access Mode: https://www.opendemocracy.net/od-russia/ gulzat-botoeva/kyrgyz-migrant-workers-does-national-pride-mean-violence-against-women

Brednikova O., Tkach O. (2010). Reshaping living space. Concepts of Home Represented by Women Migrants Working in Saint Petersburg / In: Gdaniec Cordula (eds.) Cultural Diversity in Russian Cities. Urban Landscape in post-Soviet Era. Berghahn Books. Pp. 70-93.

Buffel T., Phillipson C. (2016). Construction of 'Home' Among First-Generation Migrants Living in Belgium and England / In: Walsh K., Näre L. Transnational Migration and Home in Old Age. New York: Routledge. Pp. 63-74.

Debuis A., Thorns D. (1998). 'Home, Home Ownership and the Search for Ontological Security'. Sociological Review, 46.1. Pp. 24-47.

Federal Migration Service. The data was obtained on the official request in 2015.

Federal Migration Service. The data was obtained on the official request in 2016.

Focus Economics. Russia Economic Outlook. 21.10.2016. [Electronic Resource]. Access Mode: http:// www.focus-economics.com/countries/russia

Fryer P., Virkkunen J., Usmonov F. (2016). What Kind of Choice? Understanding Migration in Tajikistan / In: Liikanen I., Scott J.W., Sotkasiira T. (eds.). Borders, Migration and Regional Stability in the EU's Eastern Neighborhood. New York: Routledge. Pp. 182-197.

Giddens A. (1996). The Consequences of Modernity. Cambridge: Polity. 186 p.

Gritsjuk M. Vjezžaem v Novyj god. Konstantin Romodanovskiy: Kak vstretit Rossija migrantov v 2015. Rossijskaja Gazeta, 28.12.2014. [Electronic Resource]. Access Mode: http://www.rg.ru/2014/12/29/ romodanovskij.html

IOM. Tajik Migrants with Re-entry Bans to the Russian Federation. Dushanbe: IOM, 2014. [Electronic Resource]. Access Mode: https://publications.iom.int/books/tajik-migrants-re-entry-bansrussian-federation

ITAR-TASS. 600,000 migrants banned from entering Russia. 25.2.2015. [Electronic Resource]. Access Mode: http://tass.ru/en/russia/720901 
Kazmierkiewicz P. (2016). Migrant Vulnerabilities and Integration Needs in Central Asia: Root Causes, Social and Economic Impact of Return Migration - Regional Field Assessment in Central Asia 2016. Astana: International Organization for Migration (IOM). 257 p.

Kluczewska K. (2014). Migrants Re-entry Bans to the Russian Federation: The Tajik Story. Central Asia Security Policy Briefs 16, Bishkek: OSCE Academy. 17 p.

Kosmarskaya N., Savin I. (2016). Everyday nationalism in Russia in European context: Moscow residents' perceptions of ethnic minority migrants and migration / In: Kolstø P., Blakkisrud H. (eds.). The New Russian Nationalism: "Imperialism, Ethnicity and Authoritarianism 2000-2015". Edinburgh: Oxford University Press. Pp. 132-159.

Luhn A. Why are migrants fleeing Moscow? Guardian. 08.06.2015. [Electronic Resource]. Access Mode: https://www.theguardian.com/cities/2015/jun/08/why-migrants-fleeing-moscow-permitseconomy

Noble G. (2005). The Discomfort of Strangers: Racism, Incivility and Ontological Security in a Relaxed and Comfortable Nation. Journal of Intercultural Studies, 26:1. Pp. 107-120.

Peshkova V. (2015). Migrant Infrastructure in Russian Cities: the Case of Labour Migrants from Uzbekistan and Kyrgyzstan in Moscow // Mir Rossii. Vol. 24, 2. Pp. 129-151. (in Russian)

Ralph D., Staheli L.A. (2011). Home and Migration: Mobilities, Belongings and Identities. Geography Compass, 5/7. Pp. 517-530.

Rocheva A. (2014). "A Swarm of Migrants in our Maternity Clinics!": The Study of Stratified Reproduction Regime in the Case of Kyrgyz Migrants in Moscow // The Journal of Social Policy Studies. Vol. 12. No. 3. Pp. 367-380. (in Russ)

Ryazantsev S. Labour Migration from Central Asia to Russia in the Context of the Economic Crisis. Russia in Global Affairs. [Electronic Resource]. Access mode: http://eng.globalaffairs.ru/valday/ Labour-Migration-from-Central-Asia-to-Russia-in-the-Context-of-the-Economic-Crisis-18334

Ryazantsev S., Manshin R. (2016). Special features of the adaptation of migrant workers from Asian countries in the Russian economy // Central Asia and Caucasus. Vol. 17. Issue 4. P. 95-103.

Strazds A., Grennes T. The Russian Economic Crisis: How Severe and How Long? Economonitor. 17.5.2016. [Electronic Resource]. Access Mode: https://shar.es/187ycx

Tursunbekova A. Kyrgyzstan: Videos Abound of 'Patriotic' Attacks on Migrant Women in Russia. Global Voices, 16.6.2012. [Electronic Resource]. Access Mode: https://globalvoices. org/2012/06/16/kyrgyzstan-patriotic-attacks-against-migrant-women-fuel-outrage/

Varshaver E., Rocheva A. Migrant communities in Moscow: Their origins, functionality, and maintenance mechanisms. Russian Presidential Academy of National Economy and Public Administration. 2014. [Electronic Resource]. Access Mode: http://ssrn.com/abstract=2426477 (in Russian)

Varshaver E., Rocheva A., Kochkin E., Kuldina E. Kyrgyz Migrants in Moscow: Results of a Quantitative Research on Integration Tracks. Russian Presidential Academy of National Economy and Public Administration. 2014. [Electronic Resource]. Access Mode: https://ssrn.com/abstract=2425312 (in Russian)

Virkkunen J., Fryer P. (2015). Keskiaasialaiset ja Venäjän työmarkkinoiden muutos // Idäntutkimus. No. 2. Pp. 49-65.

Virkkunen J. (2013). Foodscapes in Central Asian Migrants in Russia / In: Migration bridges in Eurasia. The materials of the V International conference "Labour migration in the Russian Federation: the prevention of forced labour, the promotion of social-economic development, improvement regulation”. Ed. by S.V. Ryazantsev. Moscow: Econ-inform. Pp. 296-302.

(C) J. Virkkunen, 2017 
Acknowledgements:

The study was conducted with support from the Strategic Research Council of the Academy of Finland.

Article history:

Received: 12 December 2016

Revised: 10 January 2017

Accepted: 19 January 2017

For citation:

Virkkunen J. (2017) Economic Aspects of Migration from Central Asia in Russia. RUDN Journal of Economics, 25 (1), 102-111.

\title{
Bio Note:
}

Joni Virkkunen, $\mathrm{PhD}$ (Geography), Senior Researcher, Karelian Institute, University of Eastern Finland, Joensuu (Finland). Contact information: e-mail: Joni.virkkunen@uef.fi

\section{ЭКОНОМИЧЕСКИЕ АСПЕКТЫ МИГРАЦИИ ИЗ СТРАН ЦЕНТРАЛЬНОЙ АЗИИ В РОССИИ}

\author{
Йони Вирккунен \\ Университет Восточной Финляндии \\ ул. Улиопистокату, 2, ПЛ 111, Йоэнсуу, Финляндия, 80101
}

\begin{abstract}
Чувство «дома» и «онтологической безопасности» является центральным в социальной и психологической интеграции как мигрантов, так и местных жителей. В России для большинства центральноазиатских мигрантов восприятие «дома» часто находится в явном противоречии с реальными ежедневными практиками в России. Ухудшение экономической ситуации, падение курса рубля и амбивалентное миграционное законодательство, безусловно, влияют на интеграцию мигрантов и чувство безопасности в новой стране проживания.
\end{abstract}

Ключевые слова: онтологическая безопасность, страны Центральной Азии, миграция в Россию, миграционный кризис, интеграция мигрантов в принимающее общество

\section{История статьи:}

Дата поступления в редакцию: 12 декабря 2016

Дата принятия к печати: 19 января 2017

\section{Для цитирования:}

Вирккунен Йони. Экономические аспекты миграции из стран Центральной Азии в России // Вестник Российского университета дружбы народов. Серия: Экономика. 2017. Т. 25. № 1. C. 102-111.

\section{Сведения об авторе:}

Йони Вирккунен, доктор географических наук, ведущий исследователь Карельского института Университета Восточной Финляндии, Йоэнсуу. Контактная информация: e-mail: Joni.virkkunen@uef.fi 